\title{
POPULATION BIOLOGY OF SEABOB-SHRIMP Xiphopenaeus kroyeri (Heller, 1862) CAPTURED ON THE SOUTH COAST OF PERNAMBUCO STATE, NORTHEASTERN BRAZIL
}

\author{
Danilo Francisco Corrêa Lopes ${ }^{1 *}$, Emanuell Felipe Beserra da Silva ${ }^{2}$, Silvio Ricardo \\ Maurano Peixoto ${ }^{1}$, Flavia Lucena Frédou ${ }^{1}$ \\ ${ }^{1}$ Departamento de Pesca e Aquicultura, Universidade Federal Rural de Pernambuco \\ UFRPE) (Rua D. Manuel de Medeiros, sn, Dois irmãos, 52171-900, Recife, PE, Brasil) \\ 2 Departamento de Gestão e Tecnologia Agroindustrial (DGTA), Universidade Federal da Paraíba \\ (Campus III, 58220-000 Bananeiras, PA, Brasil)
}

*Corresponding author: danilo.correa.1@hotmail.com

http://dx.doi.org/10.1590/S1679-87592014079706204

\begin{abstract}
A B S TR A C T
This paper aims to describe the population dynamics and to evaluate the stock of the seabob-shrimp Xiphopenaeus kroyeri on the coast of Pernambuco. Sampling was carried out between August/2011 and July/2012 in Sirinhaém, southern coast of Pernambuco. A total of 1201 individuals were analyzed, 673 females and 528 males. Total length (Lt) of females varied from 4.5 to $13.5 \mathrm{~cm}$ while the Lt of males ranged between 4.0 and $11.0 \mathrm{~cm}$. The relationship between the $\mathrm{Lt}$ and carapace length and $\mathrm{Lt}$ and total weight showed negative allometry (males, females and pooled sexes). The slope of the curve "b" was statistically different between males and females for both relationships. Females mature with $8.90 \mathrm{~cm}$. Asymptotic length $\mathrm{L} \infty$ was lower for males than for females (12.26 to 14.79 and 10.72 to $11.5 \mathrm{~cm}$, respectively), $\mathrm{K}$ was similar between sexes $(1.00-2.04$ and $1.00-2.63 \mathrm{~cm} /$ year1 respectively) as well as the longevity and size at 1 st capture (1.50 to 1.97$)$ years and 7.9 to $8.9 \mathrm{~cm}$ for males and females, respectively). The results indicate that $X$. kroyeri in the region is not overexploited for males, however considering females and pooled sexes the stock is near to being fully exploited.
\end{abstract}

\section{RESUMO}

Este trabalho tem por objetivo descrever a dinâmica populacional e avaliar o estoque do camarão sete-barbas Xiphopenaeus kroyeri do litoral de Pernambuco. As coletas foram realizadas entre os meses de agosto/2011 a julho/2012 em Sirinhaém, litoral sul de Pernambuco. Foram analisados 1201 exemplares, sendo 673 fêmeas e 528 machos. Comprimento total (CT) das fêmeas variou de 4,5 a $13,5 \mathrm{~cm}$ enquanto o CT dos machos variou entre 4,0 e $11,0 \mathrm{~cm}$. As relações entre o CT e comprimento da carapaça e o CT e peso total apresentaram alometria negativa (machos, fêmeas e sexos agrupados). O declive da curva "b" foi estatisticamente diferente entre machos e fêmeas para ambas relações. Fêmeas maturam com $8,90 \mathrm{~cm}$. O comprimento assintótico L $\infty$ foi menor para os machos do que para as fêmeas (10,72-11,5 e 12,26-14,79 cm respectivamente), o $\mathrm{K}$ foi similar entre sexos (1,00-2,04 e 1,00-2,63cm/ano-1 respectivamente) assim como a longevidade e tamanho de $1^{\text {a }}$ captura (1,50-1,97anos e 7,9-8,9 cm para machos e fêmeas, respectivamente). Os resultados indicam que o estoque de $X$. kroyeri na região não se encontra sobreexplorada para os machos, entretanto considerando as fêmeas e sexos agrupados o recurso se encontra próximo do limite máximo de exploração.

Descriptors: Penaeidae, Growth, Mortality, Maturity.

Descritores: Penaeidae, Crescimento, Mortalidade, Maturidade.

\section{INTRODUCTION}

The Atlantic seabob, Xiphopenaeus kroyeri (HELLER, 1862) (Decapoda; Dendrobranchiata; Penaeidae), is a shrimp widely distributed in the western Atlantic Ocean, between Virginia, in the United States, and southern Brazil (COSTA et al., 2003). This species is found primarily at depths of between 5 and $27 \mathrm{~m}$, and in waters with salinity of 
between 9 and 36.5 (D'INCAO, 2002; SANTOS; FREITAS, 2006; SANTOS; SILVA, 2008).

In contrast with other penaeid shrimps, the juvenile $X$. kroyeri do not depend on estuaries for their development (HOLTHUIS, 1980; PAIVA, 1971; WILLIAMS, 1965; BRANCO, 2005). Populations of this species are not stratified, and juveniles and adults are commonly found within the same area (VIEIRA, 1947; NEIVA; WISE, 1967; IWAI, 1973; BRANCO, 2005).

In Brazil, shrimp are captured on a large scale, and this activity has considerable economic, historical, social, and cultural importance (BRANCO, 2005). An estimated 38,729 t of penaeid shrimp were landed in Brazil in 2011, corresponding to $67.4 \%$ of the total catch of crustaceans, with the Atlantic seabob accounting for the larger part of this total, with 15,417.8 t (MPA, 2012). In the Brazilian Northeast, trawling targeting shrimps is an artisanal activity involving both motorized vessels and sailboats (NETO, 2011). In this region, approximately 100,000 people depend directly or indirectly on the fishery of these crustaceans for their living (SANTOS et al., 2006a).

The population dynamics of $X$. kroyeri in Brazil have been described in a number of studies (SANTOS et al., 1969; BRANCO et al., 1994; CAMPOS et al., 2011; FERNANDES et al., 2011; HECKLER et al., 2013a). In the Brazilian Northeast, specifically on the coast of the state of Pernambuco, studies have focused on reproductive patterns (COELHO; SANTOS, 1983), fishery (SANTOS; COELHO, 1995, 1998; TISCHER; SANTOS, 2002), and its socio-economic aspects (TISCHER, 2003), and general biology (SANTOS; FREITAS, 2007; SILVA; SANTOS, 2007). However, no data are available on the population of Barra de Sirinhaém, where the state's largest bottom-trawling fleet is based (TISCHER; SANTOS, 2002). The overall lack of data on the biology of local penaeids (SANTOS et al., 2013) contributes to the absence of effective measures for the regulation of shrimp trawling in Pernambuco, in contrast with other Brazilian states, including those of the Northeast, where there is effective regulatory legislation.

The present study describes the biology of $X$. kroyeri, including length at first sexual maturity, growth and mortality of this species caught in the region of Barra de Sirinhaém, southeastern Pernambuco. The results of this study may contribute to the elaboration of guidelines for the sustainable shrimp fishery in the Brazilian state of Pernambuco.

\section{Material ANd Methods}

The study area is located off the coast of Barra de Sirinhaém, located on the southern coast of the Brazilian state of Pernambuco, $70 \mathrm{~km}$ south of the state capital, Recife (Fig. 1).

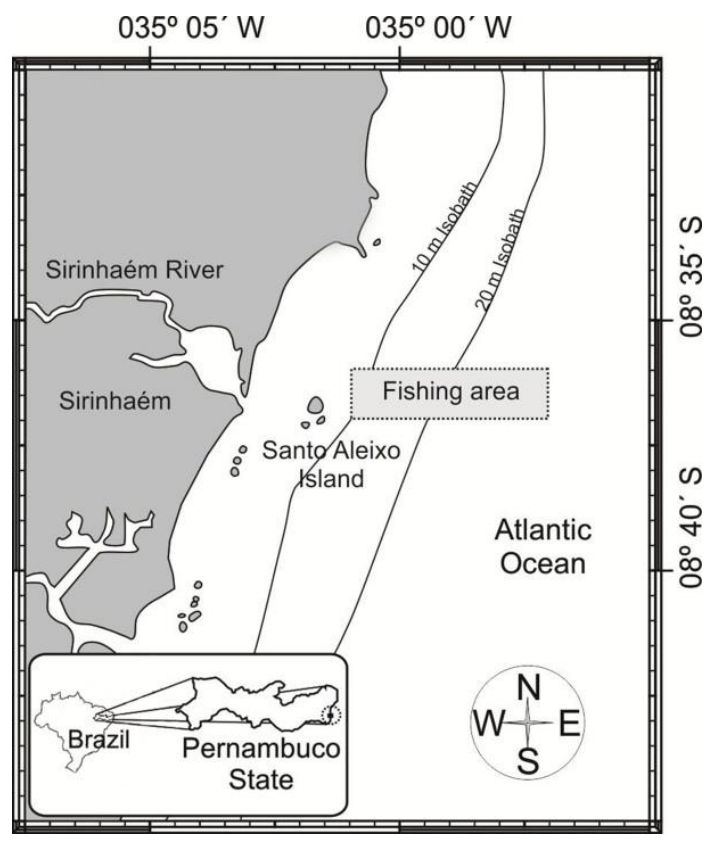

Fig. 1. Study area, Municipality of Sirinhaém, State of Pernambuco, Northeastern Brazil.

Specimens were collected each month at full moon, between August 2011 and July 2012, using a 9meter local wooden-hulled shrimping trawler. The trawls were conducted during the daytime with a double trawl measuring $10 \mathrm{~m}$ in length, with a $6.10 \mathrm{~m}$ mouth, and meshes of $30 \mathrm{~mm}$ in the main body, and 25 $\mathrm{mm}$ in the codend. Each sample was taken from three trawls conducted over a two- to three-hour period, with 100 specimens (approximately 34 from each trawl) being selected randomly, generating a total sample of 1201 specimens. The specimens were stored on ice in coolers for transportation to the laboratory.

The sex of the specimens was determined based on external morphology (presence of the thelycum in the females and petasma in the males). Two measurements were then taken of each specimen using a digital caliper - the cephalothorax length (Lc) measured from the base of the rostrum to the posterior margin of the carapace, and the total length $(\mathrm{Lt})$, from the tip of the rostrum to that of the telson. The specimens were also weighed ( $\mathrm{Wt}$, total wet weight) on an analytical balance (precision of $0.1 \mathrm{~g}$ ).

The population structure of $X$. kroyeri was evaluated through the length frequency distribution (Lt) considering sex and month. An ANOVA was used to evaluate the differences between months and between sexes, using the $\log$-transformed $(\log 10[\mathrm{x}+1])$ 
data, in order to satisfy the assumptions of normality (Kolmogorov-Smirnov) and homoscedasticity (Levene's test). The Bonferroni test was then used to evaluate the significance of differences between months.

Linear and nonlinear regressions were used to evaluate the relationships between biometric parameters, with the total length (Lt) being defined as the independent variable, and total weight and cephalothorax length (Lc) as the dependent variables. A linear relationship was found between the two length measurements $(y=a+b \cdot x)$, where $y=\mathrm{Lc} ; x=$ $\mathrm{Lt} ; a=$ intersection of the curve on the $y$ axis when $x=$ 0 , and $b=$ the slope of the curve or the constant rate of variation of $y$ as a function of $x$. Growth was evaluated as negatively allometric when $b<1$, in other words, when the dependent variable $(y)$ increases at a lower rate than the independent variable $(x)$, or positively allometric, when $b>1$, i.e., when the dependent variable $(y)$ increases at a higher rate than the independent variable $(x)$. When $b=1$, isometric growth occurs, and the two variables ( $x$ and $y$ ) grow at the same rate.

The relationship between total length and weight was nonlinear $(y=a . x b)$, where $y=\mathrm{Lt}, x=\mathrm{Wt}$, $a=$ the intersection of the curve on the $y$ axis when $x=$ 0 , and $b=$ slope of the curve or a constant rate of variation of $y$ as a function of $x$. Once again, when $b<$ 3 , growth is considered to be negatively allometric, $b$ $>3$ as positively allometric, and $b=0$ as isometric (FONTELES-FILHO, 1989). A $t$ test was applied to evaluate the isometric nature of the relationship between the variables, with a 5\% significance level (ZAR, 2010).

The proportion of males and females in the monthly and total samples was evaluated using Chisquare $\left(\chi^{2}\right)$, with a $5 \%$ significance level. To define size at first sexual maturity in the females, the percentage of adults by length class (dependent variable $y$ ) was calculated for each $0.5 \mathrm{~cm}$ size class and plotted against total length (independent variable $x$ ). Specimens were considered to be adults when they presented well-developed or spent gonads, as defined by CAMPOS et al. (2009) and MARTINS et al. (2013). These values were adjusted to a logistic curve using an iterative least squares approach, to obtain the value of L50 using KING'S (1995) logistic equation:

$\mathrm{P}=1 /[1+\exp (-\mathrm{r}(\mathrm{Lt}-\mathrm{L} 50))]$

Where $P=$ the percentage of adult females in a given length class, $r$ is the slope of the curve, $\mathrm{Lt}$ is the upper limit of the total length class, and L50 $=$ mean length at first maturation.

The length frequency distribution data were analyzed using the FISAT II (FAO / ICLARM from Assessment Tools) package (GAYANILO et al., 2005). Growth was described using VON
BERTALANFFY'S (1938) model, based on the equation:

$$
\mathrm{Lt}=\mathrm{L} \infty[1-\exp \{-\mathrm{K}(\mathrm{t}-\mathrm{t} 0)\}]
$$

Where $\mathrm{Lt}=$ length $(\mathrm{cm})$ at age $t$ (in months), $\mathrm{L} \infty=$ the asymptotic length $(\mathrm{cm}), \mathrm{K}=$ growth coefficient $(\mathrm{cm}-$ year), and $\mathrm{t} 0=$ the age at which length is zero.

To determine the parameters of von Bertalanffy's growth curve, the length values were allocated to $0.5 \mathrm{~cm}$ classes for the males, females, and all specimens together (complete dataset), for each month of the study period, in order to define the mean length at a given age, based on the method of BHATTACHARYA (1967). Based on the mean length of each cohort, defined by this approach, growth parameters were calculated based on the APPELDOORN (1987), length-at-age and Munro models. In order to obtain the best fit for the von Bertalanffy growth model, the length data were also restructured in ELEFAN (GAYANILO et al., 2005), which is available in FISAT II.

The instantaneous coefficient of total mortality (Z) was calculated; using the catch curve approach of RICKER (1975) and BEVERTON and HOLT'S (1956) model. Natural mortality (M) was estimated using RIKHTER and EFANOV'S (1976) empirical formula, which demonstrates the association between natural mortality and the age at which $50 \%$ of the population is considered to be mature. The age at first maturity (t50) was obtained by converting L 50 by the inverse VON BERTALANFFY (1938) equation. This estimate was considered for both sexes together. Fishery mortality $(F)$ was determined by the difference between $\mathrm{Z}$ and $\mathrm{M}$. The exploitation rate was estimated by the ratio between fishery $(\mathrm{F})$ and total mortality (Z). Longevity was estimated from the equation tmax $=3 / \mathrm{K}$ (TAYLOR, 1958; PAULY, 1980). The length at first capture (L50) was assumed to be the length that corresponds to a 50\% probability of capture. BEVERTON and HOLT'S (1966) yield/recruitment $(\mathrm{Y} / \mathrm{R})$ model was used to estimate the maximum sustainable yield (EMSY).

\section{RESULTS}

A total of 1201 X. kroyeri specimens were examined (Table 1), of which 673 were female and 528 males (sex ratio of 1:0.78). The females varied considerably in total length (Lt), with a mean of $9.28 \pm 1.33 \mathrm{~cm}$ (mean \pm standard deviation), and a range of $4.5 \mathrm{~cm}$ to $13.5 \mathrm{~cm}$. Males ranged in total length from 4.0 to $11.0 \mathrm{~cm}$, with a mean of $8.75 \pm 1.00$ $\mathrm{cm}$. Mean total length for the population as a whole was $9.00 \pm 1.22 \mathrm{~cm}$.

The female $X$. kroyeri were significantly longer $(P<0.05)$, on average, than males in all the 
months between November 2011 and May 2012, which coincides with the period when the largest shrimps were collected. The smallest shrimps of both sexes were collected in August and September 2011 and June and July 2012 (Fig. 2).

The relationship between total and cephalothorax lengths (Table 1) indicated significantly negative allometric growth $(\mathrm{P}<0.05)$ in males and females, as well as for grouped sexes. Growth coefficients in males and females were significantly different $(\mathrm{P}<0.05)$. The relationship between total length $(\mathrm{cm})$ and weight $(\mathrm{g})$ for males, females and grouped sexes was also significant $(\mathrm{P}<0.05)$, indicating negative allometry in all cases (Table 1). The "b" coefficient was significantly different $(\mathrm{P}<$ 0.05 ) between males and females (Table 1).

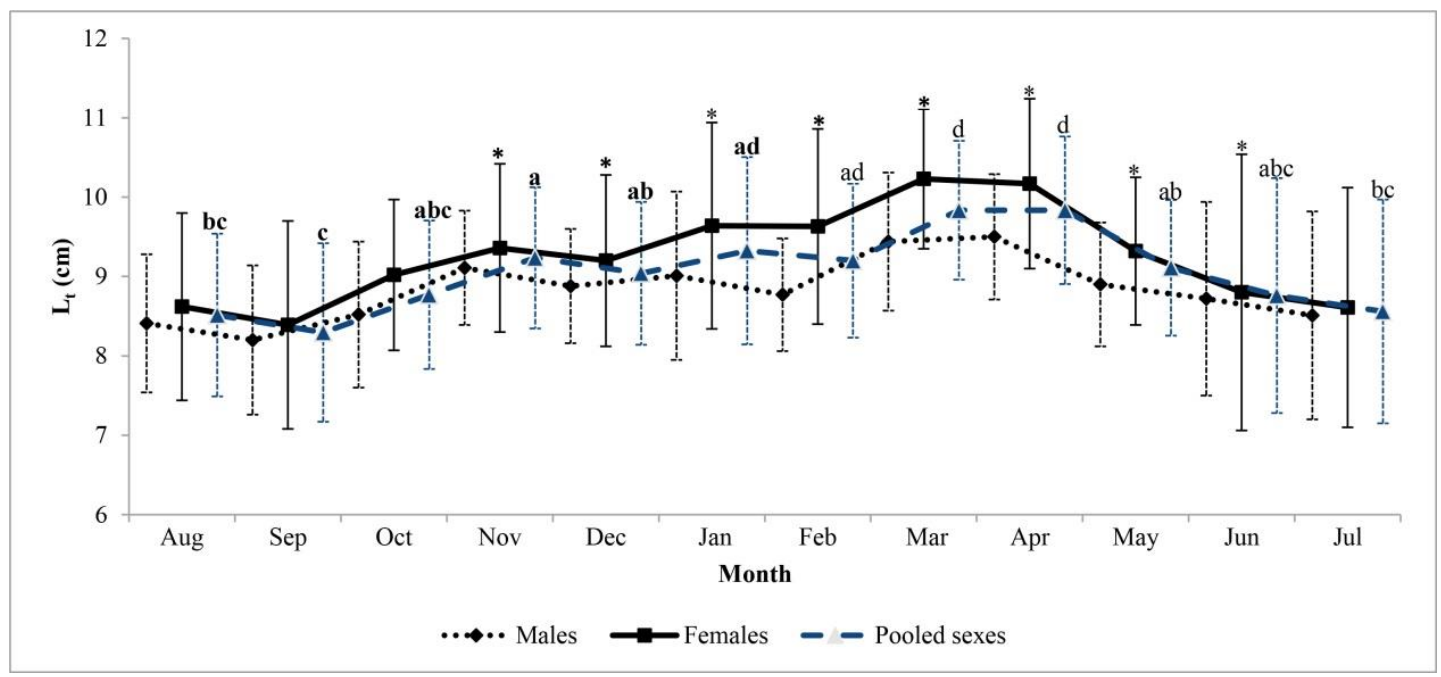

Fig. 2. Monthly mean $( \pm \mathrm{SD})$ in total length $(\mathrm{Lt})(\mathrm{cm})$ of males, females and pooled sexes of $X$. kroyeri captured from August 2011 to July 2012, at Sirinhaém, State of Pernambuco, Northeastern Brazil. Different letters indicate significant differences between months. * Significant differences between males and females.

Table 1. Relation Lt (total length, $\mathrm{cm}$ ) and Lc (cephalothorax length, $\mathrm{cm}$ ) and relation Lt (total length, $\mathrm{cm}$ ) and Wt (total weight, g) for males, females and pooled sexes of X. kroyeri captured between August 2011 and July 2012, at Sirinhaém, State of Pernambuco, Northeastern Brazil. $\mathrm{N}=$ number of individuals. $y=\mathrm{Lc}$ and $\mathrm{Wt} ; x=\mathrm{Lt} ; a=$ intersection of the axis of the straight $y$ when $x=0 ; b=$ slope of the curve or coefficient of allometry and $\mathrm{r} 2=$ determination coefficient.

\begin{tabular}{lllll}
\hline \hline Sex & $\mathbf{N}$ & $\boldsymbol{y}=\boldsymbol{a}+\boldsymbol{b} \boldsymbol{x}$ & Allometry & $\mathbf{r 2}$ \\
\hline Males & 673 & $\mathrm{Lc}=0.2214^{*} \mathrm{Lt}+0.1067$ & Negative & 0.57 \\
Females & 528 & $\mathrm{Lc}=0.2212^{*} \mathrm{Lt}-0.1048$ & Negative & 0.70 \\
Grouped sexes & 1201 & $\mathrm{Lc}=0.2174 * \mathrm{Lt}-0.0931$ & Negative & 0.67 \\
Sex & $\mathbf{N}$ & $\boldsymbol{Y}=\boldsymbol{a} . \boldsymbol{X} \boldsymbol{b}$ & Allometry & $\mathbf{r 2}$ \\
Males & 528 & $\mathrm{Wt}=0.0116 . \mathrm{Lt} 2.65$ & Negative & 0.82 \\
Females & 673 & $\mathrm{Wt}=0.0063 . \mathrm{Lt} 2.96$ & Negative & 0.87 \\
Grouped sexes & 1201 & $\mathrm{Wt}=0.0069 . \mathrm{Lt} 2.91$ & Negative & 0.85
\end{tabular}


Overall, there was a significant predominance $(\mathrm{P}<0.05)$ of females over males, and the same pattern was observed in December 2011 and April and June 2012 (Table 2). There was also a significant predominance $(\mathrm{P}<0.05)$ of females in the $4.5-5.0 \mathrm{~cm}$ and $10.0-13.5 \mathrm{~cm}$ length classes, whereas the males were significantly more common than females in the 9.0-9.5 cm class (Table 3 ).

Table 2. Monthly number $(\mathrm{N})$, percentage $(\%)$ of male and female $(\mathrm{N})$, sexual ratio of $X$. kroyeri captured from August 2011 to July 2012, at Sirinhaém, State of Pernambuco, Northeastern Brazil. * significant difference

\begin{tabular}{lllllll}
\hline \hline Month & Male & \multicolumn{3}{c}{ Female } & Total & Ratio \\
& $\mathrm{N}$ & $(\%)$ & $\mathrm{N}$ & $(\%)$ & & \\
\hline Aug-11 & 48 & 48.5 & 51 & 51.5 & 99 & $0.94: 1$ \\
Sep-11 & 48 & 55.8 & 38 & 44.2 & 86 & $1.26: 1$ \\
Oct-11 & 69 & 57 & 52 & 43 & 121 & $1.33: 1$ \\
Nov-11 & 49 & 43.4 & 64 & 56.4 & 113 & $0.77: 1$ \\
Dec-11 & 50 & 39.1 & 78 & 60.9 & 128 & $0.64: 1^{*}$ \\
Jan-12 & 40 & 40 & 60 & 60 & 100 & $0.67: 1^{*}$ \\
Feb-12 & 43 & 36.1 & 76 & 63.9 & 119 & $0.56: 1^{*}$ \\
Mar-12 & 23 & 31.9 & 49 & 68.1 & 72 & $0.47: 1^{*}$ \\
Apr-12 & 24 & 30.4 & 55 & 69.6 & 79 & $0.44: 1^{*}$ \\
May-12 & 40 & 51.9 & 37 & 48.1 & 77 & $1.08: 1^{*}$ \\
Jun-12 & 33 & 35.1 & 61 & 64.9 & 94 & $0.54: 1^{*}$ \\
Jul-12 & 61 & 54 & 52 & 46 & 113 & $1.17: 1$ \\
Total & 528 & & 673 & & 1201 & $0.78: 1^{*}$ \\
\hline
\end{tabular}

Table 3. Number $(\mathrm{N})$ and percentage $(\%)$ of male and female by length classes and sexual ratio of $X$. kroyeri captured between August 2011 and July 2012, at Sirinhaém, State of Pernambuco, Northeastern Brazil. * significant difference

\begin{tabular}{|c|c|c|c|c|c|c|}
\hline \multirow[t]{2}{*}{ Class } & \multicolumn{2}{|c|}{ Male } & \multicolumn{2}{|c|}{ Female } & \multirow[t]{2}{*}{ Total } & \multirow[t]{2}{*}{ Ratio } \\
\hline & $\mathrm{N}$ & $\%$ & $\mathrm{~N}^{\mathrm{o}}$ & $\%$ & & \\
\hline $4-4.5$ & 1 & 100 & 0 & 0 & 1 & $0: 1$ \\
\hline $4.5-5$ & 0 & 0 & 2 & 100 & 2 & $0: 2$ \\
\hline $5-5.5$ & 1 & 33.3 & 2 & 66.7 & 3 & $0.5: 1$ \\
\hline $6-6.5$ & 5 & 38.5 & 8 & 61.5 & 13 & $0.63: 1$ \\
\hline $6.5-7$ & 20 & 54.1 & 17 & 45.9 & 37 & $1.18: 1$ \\
\hline $7-7.5$ & 17 & 42.5 & 23 & 57.5 & 40 & $0.74: 1$ \\
\hline $7.5-8$ & 45 & 54.9 & 37 & 45.1 & 82 & $1.22: 1$ \\
\hline $8-8.5$ & 64 & 48.9 & 67 & 51.1 & 131 & $0.96: 1$ \\
\hline $8.5-9$ & 96 & 52.2 & 88 & 47.8 & 184 & $1.09: 1$ \\
\hline $9-9.5$ & 117 & 60.9 & 75 & 39.1 & 192 & $1.56: 1 *$ \\
\hline $9.5-10$ & 99 & 48.3 & 106 & 51.7 & 205 & 0.93:1 \\
\hline $10-10.5$ & 40 & 28.2 & 102 & 71.8 & 142 & $0.39: 1 *$ \\
\hline $10.5-11$ & 21 & 22.6 & 72 & 77.4 & 93 & $0.29: 1 *$ \\
\hline $11-11.5$ & 2 & 5.3 & 36 & 94.7 & 38 & $0.06: 1 *$ \\
\hline $11.5-12$ & 0 & 0 & 23 & 100 & 23 & $0: 23^{*}$ \\
\hline $12-12.5$ & 0 & 0 & 10 & 100 & 10 & $0: 10^{*}$ \\
\hline $12.5-13$ & 0 & 0 & 4 & 100 & 4 & $0: 4^{*}$ \\
\hline 13-13.5 & 0 & 0 & 1 & 100 & 1 & $0: 1$ \\
\hline Total & 528 & & 673 & & 1201 & $0.49: 1$ \\
\hline
\end{tabular}

The estimate of length at first maturation (L50) of the females was $8.90 \mathrm{~cm}$ (Fig. 3). The lowest
Lt value recorded for a mature female was $6.5 \mathrm{~cm}$, and all the females over $11.5 \mathrm{~cm}$ in length were mature.

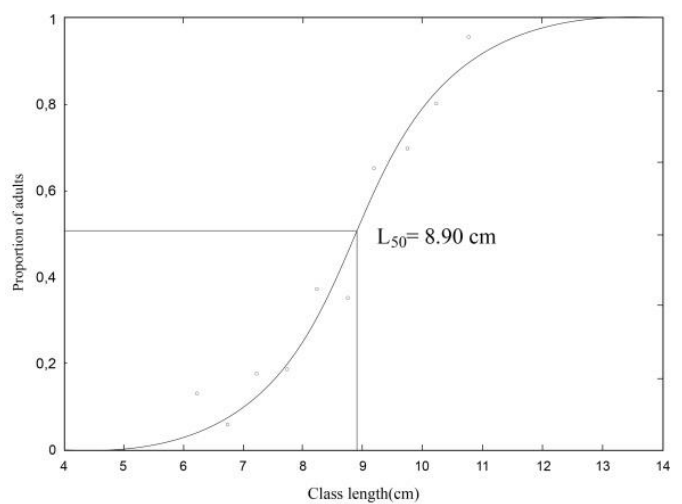

Fig. 3. Length at first maturity for females (L50) of X. kroyeri captured between August 2011 and July 2012, at Sirinhaém, State of Pernambuco, Northeastern Brazil.

The growth parameters ( $\mathrm{L} \infty$ and $\mathrm{K}$ ) obtained using the different models (Appledoorn, Length-atage, Munro, and ELEFAN I) were all higher for females than for males. The $\mathrm{L} \infty$ values varied from $12.26 \mathrm{~cm}$ to $14.79 \mathrm{~cm}$ for females, $10.72 \mathrm{~cm}$ to 11.5 $\mathrm{cm}$ for males, and $12.38 \mathrm{~cm}$ to $14.18 \mathrm{~cm}$ for grouped sexes. The $\mathrm{K}$ values were broadly similar between sexes, ranging from $1.00 \mathrm{~cm}$ to $2.63 \mathrm{~cm}$.year-1 for females, $1.00 \mathrm{~cm}$ to $2.04 \mathrm{~cm}$.year-1 for the males, and $1.00 \mathrm{~cm}$ to $2.83 \mathrm{~cm}$.year-1 for grouped sexes (Table 4).

Table 4. Estimation of growth parameters $\mathrm{L} \infty(\mathrm{cm})$ and $\mathrm{K}$ (cm month-1) by different methods for males, females and pooled sexes of seabob-shrimp $X$. kroyeri model, captured between August 2011 and July 2012, at Sirinhaém, State of Pernambuco, Northeastern Brazil.

\begin{tabular}{llcc}
\hline \hline Methods & Sex & $\begin{array}{r}\text { Lo } \\
(\mathrm{cm})\end{array}$ & K (cm/month-1) \\
\hline Appeldoorn & Males & 10.73 & 1.00 \\
(1987) & Females & 12.26 & 1.00 \\
& Pooled & 12.38 & 1.00 \\
Length-at-age & sexes & & \\
& Males & 11.05 & 1.52 \\
& Females & 14.79 & 1.99 \\
& Pooled & 14.03 & 2.23 \\
Munro's & sexes & & \\
& Males & 10.72 & 2.04 \\
& Females & 14.42 & 2.63 \\
& Pooled & 13.60 & 2.83 \\
ELEFAN I & sexes & & \\
& Males & 11.5 & 1.25 \\
& Females & 14.18 & 1.50 \\
& Pooled & 14.18 & 1.60 \\
& sexes & & \\
\hline
\end{tabular}


The growth parameters obtained from the Length-at-age model were used to estimate mortality rates, given that the values were compatible with the biology of the species and the values available in the literature. Natural mortality (M), estimated by Rikhter \& Efanov's (1976) method, was 1.98 year-1 (t50 = 0.45 years).

The estimates of mortality for the females were, by both methods, higher than those for the males (Table 6), with higher exploitation rates (E). Similarly, body length at first capture was greater in the females $(8.89 \mathrm{~cm})$ than in the males $(7.84 \mathrm{~cm})$. Longevity was 1.97 years for the males, and 1.50 for the females. The EMSY values for the females and grouped sexes are similar to the E values derived from Ricker's capture curve approach and the Beverton-Holt method. However, the $\mathrm{E}$ values recorded for the males were lower than the EMSY (Table 5).

\section{DisCUSSION}

The female Atlantic seabob (X. kroyeri) captured off the southern coast of Pernambuco were larger and more abundant than the males. Sexual dimorphism in body size is a typical penaeid trait (BOSCHI, 1969). HARTNOLL (1982) interpreted the larger size and greater weight of females as a functional difference related to the need to accommodate the ovaries and other reproductive organs. Similar results have been obtained for other $X$. kroyeri populations (SANTOS et al., 2001; CASTRO et al., 2005; SILVA; SANTOS, 2007; LOPES et al., 2010; HECKLER et al., 2013b; MARTINS et al., 2013).

The smallest shrimps were captured mainly between June and September, which may reflect a peak in recruitment during this period, coinciding with the austral winter. In the present study, the overall sex ratio of the Atlantic seabob, X. kroyeri, was 0.78:1.00 (male:female), significantly biased towards the females $(P<0.05)$. Significant deviations in the sex ratio appear to be common in crustaceans (WENNER, 1972), and a predominance of females is a characteristic of oceanic penaeid populations. Sex ratios close to 1:1 may indicate the presence of breeding grounds (COELHO; SANTOS, 1993, 1995). Sex ratios may also vary by size class in penaeids (GARCIA; LE RESTE, 1986), with the females generally predominating in the larger body length classes. A similar tendency was observed in the present study, where the females presented a wider range of body lengths and were more abundant in the larger size classes.

Length at first sexual maturity is a fundamental parameter for the sustainable management of fishery stocks (FONTELES-FILHO, 2011), and is widely used as the minimum body size threshold for the exploitation of a target species. In the present study, length at first maturation (L50) was $8.90 \mathrm{~cm}$ for the females. The shortest mature female was $6.5 \mathrm{~cm}$ in length $(\mathrm{Lt})$, while all those of over 11.5 $\mathrm{cm}$ in length were mature. MARTINS et al. (2013) recorded a similar L50 value of $9.02 \mathrm{~cm}$ for $X$. kroyeri off the central and southern coast of the Brazilian state of Espírito Santo. Variations in the L50 values among different geographic regions may be related to environmental factors, such as seasonality, latitude, and the depth of the water (DALL et al., 1990), or to differences in harvesting levels, which may provoke modifications in the timing of sexual maturation (SPARRE; VENEMA, 1997; FONTELES-FILHO, 2011). In the present study, length at first capture was $8.96 \mathrm{~cm}$ for the females and $7.94 \mathrm{~cm}$ for the males, values similar to the estimated length at first maturity, which indicates that the shrimps are harvested at a body size at which they are contributing to stock recruitment.

The $b$ coefficient of the Lt-Lc relationship was consistent with negative allometric growth in the males, females, and both sexes combined, with the cephalothorax growing at a slower rate than the total length of the shrimp. A similar pattern was observed for males by BRANCO et al. (2005) in Santa Catarina, south Brazil. Negative allometric growth was also observed in the Lt-Wt relationship, with weight increasing at a slower rate than body length. This growth pattern may be related to the onset of sexual maturity and gonadal development, which represents a considerable energetic demand on the individual during the breeding season.

Table 5. Estimates of total mortality (Z-year -1), fishing mortality (F-year -1), exploitation rates $(\mathrm{E})$, length at first capture $(\mathrm{Lc}-\mathrm{cm})$ and longevity (Year) by LengthConverted Catch Curve and Beverton and Holt methods for males, females and pooled sexes of seabob-shrimp X. kroyeri model, captured between August 2011 and July 2012, at Sirinhaém, State of Pernambuco, Northeastern Brazil.

\begin{tabular}{|c|c|c|c|c|c|c|c|c|c|}
\hline Method /Sex & Catcl & Curve & & & Beve & on \& 1 & & & \\
\hline & Z & $\mathrm{F}$ & E & LC & $\mathrm{Z}$ & $\mathrm{F}$ & E & EMSY & Long. \\
\hline Male & 4.51 & 1.46 & 0.32 & 7.94 & 4.56 & 2.02 & 0.44 & 1.00 & 1.97 \\
\hline Female & 10.6 & 7.33 & 0.69 & 8.96 & 11.5 & 8.96 & 0.78 & 0.77 & 1.50 \\
\hline Pooled sexes & 10.4 & 6.8 & 0.65 & 8.42 & 13.6 & 11.1 & 0.81 & 0.79 & 1.34 \\
\hline
\end{tabular}


Body length data are adequate for the determination of population parameters in penaeid shrimps due to the lack of rigid structures for aging in these crustaceans (ETIM; SANKARE, 1998). Peneids present a fast and discontinuous growth, limited by their chitinous exoskeleton. However, due to the high numbers of moults per year without a specific seasonality, the von Bertalanffy model, with a continuous growth model, can be used to make estimates of the growth parameters of these crustaceans (VON BERTALANFFY, 1938; GARCIA; LE RESTE, 1986; LEITE JR; PETRERE, 2006).

In penaeids, males typically present lower L $\infty$ values and higher $K$ scores than females (GARCIA; LE RESTE, 1986; DALL et al., 1990). In the present study, L $\infty$ was lower in the males (10.73$11.50 \mathrm{~cm})$ than in the females $(12.26-14.79 \mathrm{~cm})$. However, the males also presented a slightly lower growth rate $(\mathrm{K}=1.00-2.04 \mathrm{~cm}$.year- 1$)$ than the females (1.00-2.63 cm.year-1). This inversion has been reported by D'INCAO and FONSECA (1999) for a number of penaeid species, and by ISAAC et al. (1992) for Farfantepenaeus subtilis in northern Brazil. In this study, growth parameters are similar to those of other regions, although the $\mathrm{K}$ scores recorded in southern Brazil (Table 6) were lower. Growth parameters may vary in both time and space among different species, which may be related to intrinsic traits (such as genetic effects) or extrinsic forces (i.e., environmental variables), as well as geographic region, sex, and habitat (FERNANDES et al., 2011).

Table 6. Values of $\mathrm{L} \infty(\mathrm{Lt} \mathrm{cm})$ and $\mathrm{K}$ (year-1) found in the literature for $X$. kroyeri.

\begin{tabular}{|c|c|c|c|c|}
\hline \multirow[t]{2}{*}{ Location/Reference } & \multicolumn{2}{|l|}{ Male } & \multicolumn{2}{|c|}{ Female } \\
\hline & $\mathrm{L} \infty$ & $\mathrm{K}$ & $\mathrm{L} \infty$ & $\mathrm{K}$ \\
\hline Present study & 11.05 & 1.52 & 14.79 & 1.99 \\
\hline $\begin{array}{l}\text { Rio de Janeiro (Brazil)/ } \\
\text { Fernandes et al. (2011) }\end{array}$ & 13.4 & 1.93 & 14.8 & 1.65 \\
\hline $\begin{array}{l}\text { Gulf of Mexico } \\
\text { (Mexico)/ Flores- } \\
\text { Hernandéz et al. (2006) }\end{array}$ & 13.6 & 1.20 & 13.6 & 1.20 \\
\hline $\begin{array}{l}\text { Itapocoroy (Santa Catarina, } \\
\text { Brazil)/ Branco (2005) }\end{array}$ & 13.3 & 0.30 & 15.4 & 0.26 \\
\hline $\begin{array}{l}\text { Matinhos (Paraná, Brazil)/ } \\
\text { Branco et al. (1994) }\end{array}$ & 13.5 & 0.61 & 15.0 & 0.53 \\
\hline
\end{tabular}

The Peneídae present a fast and discontinuous growth, limited by chitinous shell (changes). However, due to lack of timing and high attendance seedlings per year, the von Bertalanffy model (continuous growth model) can be used to make estimates of the growth parameters of these crustaceans (VON BERTALANFFY, 1938; GARCIA; LE RESTE, 1986; LEITE JR; PETRERE, 2006).
In the present study, female $X$. kroyeri presented higher total mortality (10.6-11.5 year-1) in comparison with the males (4.51-4.56 year-1). In southern Brazil, PAIVA (1996) recorded a Z coefficient equivalent to 1.24 year- 1 over an annual cycle. The estimates of $\mathrm{Z}$ found in the present study for $X$. kroyeri are similar to those recorded for other penaeids such as $F$. subtilis (1.63-7.01 year-1; ISAAC et al., 1992), Farfantepenaeus brasiliensis and Farfantepenaeus paulensis (4.3-5.3 year-1 and 5.1-6.2 year-1, respectively; LEITE JR and PETRERE, 2006); Penaeus setiferus and Farfantepenaeus dourarum (5.43 and 6.71 year-1 and 7.07 year-1, respectively; PAULY, 1984) and Penaeus semisulcatus (6.4-8.2 year-1; NIAMAIMANDI et al., 2007). Estimated natural mortality (M) was 1.98 year-1, which is consistent with the values recorded for other penaeids, such as $F$. brasiliensis and $F$. paulensis; (1.8 year-1 and 1.9 year-1, respectively; LEITE JR and PETRERE, 2006). In Venezuela, ANDRADE DE PASQUIER and STOTZ (1999) recorded M values of 1.52-2.56 year-1 for $L$. schmitti.

Longevity values recorded in the present study were 1.66-2.40 years for males and 1.55-2.00 years for females. SANTOS et al. (2006b) estimated longevity of approximately 2.5 years for $X$. kroyeri in the Brazilian Northeast, and similar values -2.5 years for males and 2.8 years for females - were recorded by FERNANDES et al. (2011). GARCIA and LE RESTE (1986) reported that longevity in penaeids varies from 1.3 to 2.5 years.

The optimal exploitation of fishery resources is dependent on an adequate evaluation of stocks. Estimates of yields provide a general idea of the degree of exploitation of these stocks. In the present study, the maximum sustainable yield (EMSY) was 1.00 for the males and $0.73-0.77$ for the females. Asymptotic yield per recruit may occur under specific circumstances, such as a relatively large size at first capture in comparison with the asymptotic body length (BOOTH; BUXTON, 1997), as observed in the males in the present study. This type of asymptotic curve of yield per recruit may give the false impression that, above a certain size of first capture, the population would not be being overexploited in the classic sense, even if the recruitment potential is reduced by the overfishing of spawning stocks (BUXTON, 1992).

The results of the present study indicate that the local stocks of male $X$. kroyeri are not being overexploited, although their size at first capture is slightly smaller than that at first maturity. In any case, the males are harvested proportionately less than the females, which reflects their lower mortality. However, considering the females and grouped sexes (the ideal parameter for management purposes), it is clear that the resource is close to the threshold of maximum sustainable yield. Xiphopenaeus kroyeri is 
known to spawn intermittently (MARTINS et al., 2013). This characteristic, together with its short life cycle, rapid growth and development, and high rates of natural mortality indicate that the species is resilient, and that its stocks may recuperate more rapidly than those of other species with longer life cycles. The stocks of $X$. kroyeri in the study area may nevertheless become increasingly vulnerable in the future due to the lack of adequate regulatory legislation in the state of Pernambuco that would guarantee the sustainability of local stocks over the long term.

\section{ACKNOWLEDGEMENTS}

This study was partially financed by CAPES ("Coordenação de Aperfeiçoamento de Pessoal de Nível Superior") through a student grant to the first author and $\mathrm{CNPq}$ ("Conselho Nacional de Ciência e Tecnologia") through a research grant to the third and last authors and by FACEPE ("Fundação de Ciência e Tecnologia do Estado de Pernambuco") and BNB ("Banco do Nordeste do Brasil"), by financial assistance during the development of the project.

\section{REFERENCES}

ANDRADE DE PASQUIER, G.; STOTZ, W. Crecimiento y mortalidade del camarón blanco, Penaeus schmitti, en el Lago de Maracaibo, Venezuela. Zootec. Trop., v.17, p. 63-89, 1999.

APPELDOORN, R. Modification of a seasonality oscillating growth function for use with mark-recapture data. J. Conserv. CIEM, v. 43, p.194-198, 1987.

BEVERTON, R. J. H.; S. J. HOLT. A review of methods for estimating mortality rates in exploited fish populations, with special reference to sources of bias in catch sampling. Rapp. P. V. Réun. CIEM, v.140, p. 67-83, 1956.

BEVERTON, R. J. H.; S. J. HOLT. Manual of methods for fish stock assessment. Part II. Tables of yield function. FAO Fish. Biol. Tech., p. 38, 1966.

BHATTACHARYA, C.G. A simple method of resolution of a distribution into Gaussian components. Biometrics, v.23, p.115-135, 1967

BOOTH, A. J.; BUXTON, C. D. Management of the panga Pterogymnus laniarius (Pisces: Sparidae) on the Agulhas Bank, South Africa using per-recruit Models. Fish. Res., v.32, p.1 - 11, 1997.

BRANCO, J. O.; LUNARDON-BRANCO, M. J.; FINIS, A. D. E. Crescimento de Xiphopenaeus kroyeri (Heller, 1862) (Crustacea, Natantia, Penaeidae) da região de Matinhos, Paraná, Brasil. Arq. Biol. Tecnol., v.37, n.1, p.1-8,1994.

BRANCO, J.O. Biologia e pesca do camarão sete-barbas Xiphopenaeus kroyeri (Heller) (Crustácea, Penaeidae), na Armação do Itapocoroy, Penha, Santa Catarina, Brasil. Rev. Bras. Zool., v. 22, p.1050-1062, 2005.
BOSCHI, E. E. Estudio biológico pesquero del camarón Artemesia longinaris Bate, de Mar del Plata. Bol. Biol. Mar., v.18, p. 1-47,1969.

BUXTON, C. D. The application of yield-per-recruit models to two South African sparid reef species, with special consideration to sex change. Fish. Res., v. 15, p. 1-16, 1992.

CAMPOS, B. R.; DUMONT, L. F. C.; D'INCAO, F.; BRANCO, J. O. Ovarian development and length at first maturity of the sea-bob-shrimp Xiphopenaeus kroyeri (Heller) based on histological analysis. Nauplius, v. 17, n.1, p. 9-12, 2009.

CAMPOS, B. R.; BRANCO, J. O.; D'INCAO, F. Crescimento do camarão-sete-barbas (Xiphopenaeus kroyeri (Heller 1862) na baía de Tijucas, Tijucas, SC (Brasil). Atlantica, v. 33, n. 2, p. 201-208, 2011.

CASTRO, R. H.; COSTA, R. C.; FRANSOZO, A.; MANTELATTO, F. L. M. Population structure of the seabob shrimp Xiphopenaeus kroyeri (Heller, 1862) (Crustacea: Penaeidea) in the littoral of São Paulo, Braz. Sci. Mar., v.69, p. 105-112, 2005.

COELHO, P. A.; SANTOS, M. C. F. Época de reprodução do camarão sete-barbas, Xiphopenaeus kroyeri (Heller, 1862) (Crustacea, Decapoda, Penaidae) na região de Tamandaré, PE. Bol. Tec. Cient. CEPENE, v. 1, n. 1, p.171-186. 1993.

COELHO, P. A.; SANTOS, M.C.F. Época da reprodução dos camarões Penaeus schmitti Burkenroad, 1936 e Penaeus subtilis Pérez-Farfante, 1967 (Crustacea, Decapoda, Penaeidae), na região da foz do Rio São Francisco. Bol. Tec. Cient. CEPENE, v. 3, p.122-140. 1995.

COSTA, R. C.; FRANSOZO, A.; MELO, G. A. S.; FREIRE, F. A. M. chave ilustrada para identificação dos camarões Dendrobranchiata do litoral norte do estado de São Paulo, Brasil. Biota Neotropica, v.3, n.1, 2003.

DALL, W.; HILL, B. J.; ROTHLISBERG, P. C.; STAPLES, D. J. The Biology of the Penaeidae. Adv. Mar. Biol., Academic Express, London, p. 1-489, 1990.

D'INCAO, F; FONSECA, D.B. Performance of the von Bertalanffy growth curve in penaeid shrimps: a critical approach. In: The biodiversity crisis and Crustacea. Crustac. Issues Rotterdam, p.733-737, 1999.

D'INCAO, F. Estudo sobre o crescimento de Penaeus, Farfantepeneus paulensis Perez-Farfante, 1967 da Lagoa dos Patos, RS, Brasil, Decapoda, Penaeidae. Atlantica, v.7, p.73-84, 2002.

ETIM, L.; SANKARE, Y. Growth and mortality, recruitment and yield of the fresh-water shrimp, Macrobrachium völlenhovenii, Herklots 1851 (Crustacea, Palaemonidae) in the Fahe reservoir, Côte d'Ivoire, West Africa. Fish. Res., v. 38, p.211-223, 1998.

FERNANDES, L. P.; SILVA, A. C.; JARDIM, L. P.; KEUNECKE, K. A.; DI BENEDITTO, A. P. M. Growth and recruitment of the Atlantic seabob shrimp, Xiphopenaeus kroyeri (Heller, 1862) (Decapoda, Penaeidae), on the coast of Rio De Janeiro, Southeastern Brazil. Crustac., v. 84, p. 1465-1480, 2011.

FLORES-HERNANDÉZ, D.; MIRANDA, R. J.; CRIOLLO, F. G. Evaluación de la pesquería de camarón siete barbas (Xiphopenaeus kroyeri) en el sur del Golfo de México. Bol. Inf. Jaina, v.16, p.61-66, 2006.

FONTELES FILHO, A. A. Recursos Pesqueiros: Biologia e Dinâmica Populacional. Imprensa Oficial do Ceará, p. 296, 1989. 
FONTELES FILHO, A. A. Oceanografia, biologia e dinâmica populacional de recursos pesqueiros. Universidade Federal do Ceará, Instituto de Ciências do Mar, Fortaleza, Brasil. p. 1-460, 2011.

GARCIA, S.; LE RESTE, L. Ciclos vitales, dinámica, explotación y ordenación de las poblaciones de camarones peneidos costeros. FAO Doc. Tec. Pesca, v. 203, p.1 -180, 1986.

GAYANILO, F. C.; SPARRE, P.; PAULY, D. FAOICLARM Stock assessment tools II (FISAT II): User's guide. FAO Comput. Inf., Roma, Italy, p. 1-168, 2005.

HARTNOLL, R.G. Growth, p. In: D.E. Bliss (Ed.). The Biology of Crustacea. Embriology, Morphology and Genetics. New York, New York Academic Press, v. 2, p.111-185, 1982.

HECKLER, G. S.; SIMÕES, S. M.; LOPES, M.; ZARA, F. J.; COSTA, R. C. Population dynamics of these a bob shrimp Xiphopenaeus kroyeri (Dendrobranchiata, Penaeidae) in a south-eastern region of Brazil. S. Afr. J. Mar. Sci., Grahamstown, v. 35, n. 1, p. 17-24, $2013 \mathrm{a}$.

HECKLER, G. S.; SIMÕES, S. M.; LOPES, M.; ZARA, F. J.; COSTA, R. C. Biologia Populacional e Reprodutiva do camarão sete-barbas na baía de Santos, São Paulo. Bol. Inst. Pesca Sao Paulo, v. 39, n. 3, p. 283 - 297, 2013b.

HOLTHUIS, L. B. Shrimp and prawns of the world. An annoted catalogue of species of interest to fisheries. FAO Species Cat., Roma, v. 1, p. 1-261, 1980.

ISAAC, V. J.; DIAS NETO, J.; DAMASCENO, F. G. Camarão-rosa da Costa Norte: Biologia, dinâmica e administração pesqueira: (Série de Estudos de Pesca, Coleção Meio Ambiente, Brasília, Brasil), p. 1-187, 1992.

IWAI, M. Pesca exploratória e estudo biológico sobre o camarão na costa Centro/Sul do Brasil com o Navio Oceanográfico "Prof. W. Besnard" em 1969-1971. SUDELPA/ IOUSP, São Paulo, p. 71, 1973.

KING, M. Fisheries Biology. In: Assessment and Management. Oxford Press, London, p. 342, 1995.

LEITE JR, N. O.; PETRERE JR, M. Growth and mortalities of the Pink-shrimp Farfantepenaeus brasiliensis Latreille, 1970 and $F$. paulensis PÉREZ-FARFANTE 1967 in Southeast Brazil. Brazilian J. Biol., v. 66, p. 523-536, 2006

LOPES, J. B. B. S.; VASQUES, R. O.; GUIMARÃES, F. J.; CETRA, M.; COUTO, E. C. G. Proporção sexual do camarão sete-barbas Xiphopenaeus kroyeri na costa de Ilhéus, Bahia, Brasil. Bol. Inst. Pesca Sao Paulo, v. 36, n. 4, p. $251-262,2010$.

MARTINS, A. S.; PINHEIRO, H. T.; LEITE JÚNIOR, N. O. Biologia reprodutiva do camarão sete-barbas no centro sul e sul do Espírito Santo, Brasil. Bol. Inst. Pesca Sao Paulo, v. 39, n. 3, p. 205- 215. 2013.

MPA - Ministério da Pesca e Aquicultura. Bol. Estat. Pesca Aquicult., p. 129. 2012.

NEIVA, G. S.; WISE, J. P. A biologia e pesca do camarão sete-barbas da Baía de Santos, Brasil. Ver. Nac. Pesca, v.1, p. 12-19, 1967.

NETO, J. D. Proposta de Plano Nacional de Gestão para o Uso Sustentável de Camarões Marinhos do Brasil. IBAMA, Brasília, Brazil, p.1-242, 2011.

NIAMAIMANDI, N.; ARSHAD, A. B.; DAUD, S. K.; SAED, R. C.; KIABI, B. Population dynamic of green tiger prawn, Penaeus semisulcatus (De Haan) in Bushehr coastal waters, Persian Gulf. Fish. Res., v. 86, p. 105$112,2007$.

PAIVA, M. P. Tentativa de avaliação dos recursos pesqueiros do Nordeste brasileiro. Arq. Cienc. Mar., Ceará, v. 11, n. 1, p. 1-15, 1971.

PAIVA, M. P. Levantamento do estado da arte da pesquisa dos recursos vivos marinhos do Brasil. Programa REVIZEE, Ministério do Meio Ambiente, dos Recursos Hídricos e da Amazônia Legal, Brasília, p. 241, 1996.

PAULY, D. On the interrelationships between natural mortality, growth parameters and mean environmental temperature in 175 fish stocks. J. Cons. Int. Explor. Mer., v. 39, n. 3, p. 175-192, 1980.

PAULY, D. Length-converted catch curves: a powerful tool for fisheries research in the tropics (Part II). ICLARM Fish byte, v. 2, p. 17-19, 1984.

RICKER, W. E. Computation and interpretation of biological statistics of fish populations. Bull. Fish. Res. Board Can., n. 191, p. 382, 1975.

RIKHTER, V. A.; EFANOV, V. N. On one of the approaches to estimation of natural mortality of fish populations. ICNAF, v. 9, p. 65-74, 1976.

SANTOS, E. P.; NEIVA, G S.; SCHAEFFER, Y. Dinâmica da população do camarão sete-barbas, Xiphopenaeus kroyeri (Heller), na Baia de Santos. Pescarias Pesq., v. 2, n. 2, p. 41-55, 1969.

SANTOS M. C. F.; COELHO, P. A. Participação por espécie na pesca artesanal de camarões marinhos em Tamandaré, PE. Bol. Tec. Cient. CEPENE, v. 3, n. 1, p. 141 - 147, 1995.

SANTOS, M. C. F.; COELHO P. A. Recrutamento Pesqueiro de Xiphopenaeus kroyeri (HELLER, 1862) (Crustacea: Decapoda: Penaeidae) na Plataforma Continental dos Estados de Pernambuco, Alagoas e Sergipe - BRASIL. Bol. Tec. Cient. CEPENE, v. 6, n. 1, p. 1998.

SANTOS, M. C. F.; RAMOS, I. C.; FREITAS, A. E. T. S. Análise de produção e recrutamento do camarão setebarbas, Xiphopenaeus kroyeri (Heller, 1862) (Crustacea: Decapoda: Penaeidae), no litoral do Estado de Sergipe Brasil. Bol. Tec. Cient. CEPENE, v. 9, n. 1, p. 53 -71, 2001.

SANTOS, M. C. F; FREITAS, A. E. T. S. Determinação dos parâmetros biológico-pesqueiros do camarão setebarbas, Xiphopenaeus kroyeri (HELLER, 1862) (DECAPODA, PENAEIDAE), em Jequiá da Praia. Alagoas/Brasil. Bol. Tec. Cient. CEPENE, v. 14, n. 1, p. 71-91, 2006.

SANTOS, M. C. F.; PEREIRA, J. A.; IVO, C. T. C. A pesca do camarão branco, Litopenaeus shimitti (Burkenroad, 1936) (Crustacea, Decapoda, Penaeidae), no Nordeste do Brasil. Bol. Tec. Cient. CEPENE, v. 14, n. 1, p. 33-58, 2006a.

SANTOS, M. C. F. O.; COELHO, P. A.; PORTO, M. R. Sinopse das informações sobre a biologia e pesca do camarão-sete-barbas, Xiphopenaeus kroyeri (Heller, 1862) (Decapoda, Penaeidae), no Nordeste do Brasil. Bol. Tec. Cient. CEPENE, v. 14, n. 1, p. 141-178, 2006b.

SANTOS, M. C. F.; FREITAS, A. E. T. S. Avaliação biológica de camarões peneídeos capturados no município de São José da Coroa Grande/PE, Brasil. Bol. Tec. Cient. CEPENE, v. 15, n. 1, p. 63-79, 2007. 
SANTOS, M. C. F.; SILVA, C. G. M. Aspectos biológicos do camarão sete-barbas, Xiphopenaeus kroyeri (HELLER, 1862) (Crustacea, Decapoda, Penaeidae), no município de Caravelas (Bahia - Brasil). Bol. Tec. Cient. CEPENE, v. 16, n. 1, p. 85-97, 2008.

SANTOS, M. C. F.; BRANCO, J. O.; BARBIERI, E. Biologia e pesca do camarão sete-barbas nos estados nordestinos brasileiros onde não há regulamentação do período de defeso. Bol. Inst. Pesca Sao Paulo, v. 39, n. 3, p. 217- 235, 2013.

SILVA, U. M.; SANTOS, M. C. F. Biologia pesqueira do camarão sete-barbas, Xiphopenaeus kroyeri, (Heller,1862) (DECAPODA, PENAEIDAE), na APA Costa dos Corais, Tamandaré (Pernambuco- Brasil). Bol. Tec. Cient. CEPENE, v. 15, n. 2, p. 57-68, 2007.

SPARRE, P.; VENEMA, S. C. Introduction to tropical fish stock assessment. Part 1 - manual, FAO Fish. Paper, p. 1-376, 1997.

TAYLOR, C. C. Cod growth and temperature. J. Cons. Int. Explor. Mer., v. 23, p. 366-370, 1958.

TISCHER M.; SANTOS, M. C. F. Pesca e variação sazonal da ictiofauna acompanhante e dos camarões peneídeos capturados pela frota motorizada no litoral sul de Pernambuco. Bol. Tec. Cient. CEPENE, v. 10, n. 1, p. $221-238,2002$.
TISCHER, M. Aspectos socioeconômicos do aproveitamento da ictiofauna acompanhante das pescarias de camarões peneídeos, em Sirinhaém, Pernambuco - Brasil. Bol. Tec. Cient. CEPENE, v. 11, n. 1, p. 271 - 276, 2003.

VIEIRA, B. B. Observações sobre a maturação de Xiphopenaeus kroyeri no litoral de São Paulo. Bol. Mus. Nac., v. 74, p. 1-2, 1947.

VON BERTALANFFY, L. A quantitative theory of organic growth (inquiries on growth laws. II). Hum. Biol., v. 10, p. 181-213, 1938.

WENNER, A. M. Sex ratio as a function of size in marine (?). Crustac. Am. Nat., v. 106, p. 321-350, 1972.

WILLIAMS, A. B. Marine Decapod Crustaceans of the Carolinas. Fish. Bull., v. 65, p. 1-298, 1965.

ZAR, J. H. Biostatistical Analysis, $5^{\circ}$ ed, Ed. Prentice-Hall International INC, New Jersey/EUA, 2010.

(Manuscript received 10 March 2014; revised 22 August 2014; accepted 15 September 2014)

No fascículo Braz. j. oceanogr., Dec 2014, vol.62, no.4, p.331-340.

Onde se Lê:

Danilo Francisco Corrêa Lopes ${ }^{1 \star}$, Silvio Ricardo Maurano Peixoto², Flavia Lucena Frédou ${ }^{1}$, Emanuell Felipe

Beserra da Silva ${ }^{1}$

${ }^{1}$ Universidade Federal Rural de Pernambuco. (Rua Fenelon Santos, 135, 49020-350 Aracaju, SE, Brasil)

${ }^{2}$ Universidade Federal da Paraíba - Departamento de Gestão e Tecnologia Agroindustrial (DGTA). (Campus III, 58220-000 Bananeiras, PA, Brasil)

Leia-se:

Danilo Francisco Corrêa Lopes ${ }^{1 \star}$, Emanuell Felipe Beserra da Silva² ${ }^{2}$, Silvio Ricardo Maurano Peixoto ${ }^{1}$, Flavia Lucena Frédou ${ }^{1}$

${ }^{1}$ Departamento de Pesca e Aquicultura, Universidade Federal Rural de Pernambuco UFRPE) (Rua D. Manuel de Medeiros, sn, Dois irmãos, 52171-900, Recife, PE, Brasil)

${ }^{2}$ Departamento de Gestão e Tecnologia Agroindustrial (DGTA), Universidade Federal da Paraíba (Campus III, 58220-000 Bananeiras, PA, Brasil) 